\title{
KORELASI PERSEPSI SISWA TENTANG KREATIVITAS GURU PAI DENGAN HASIL BELAJAR SISWA DI SMP NEGERI 12 X 11 ENAM LINGKUNG
}

\author{
Andrianto, Edriagus Saputra, Novita Yanti, Syamsurizal, Winda Safitri \\ Institut Agama Islam Sumatera Barat Pariaman \\ E-mail: andriantotkibrahim@gmail.com, saputraedriagus@gmail.com,nofitayanti16@gmail.com, \\ syamsurizal.tandikek@gmail.com, windasafitri317@gmail.com
}

How to Cite:

Andrianto, Saputra. E., Yanti. N., Syamsurizal, Safitri, W. (2021). Korelasi Presepsi Siswa tentang Kreativitas Guru PAI dengan Hasil Belajar Siswa di SMP Negeri 12 X 11 Enam Lingkung . Fitrah: Journal of Islamic Education, 2(1), 37-51.

\section{ARTICLE HISTORY}

Received : 28 May 2021

Revised : 12 July 2021

Accepted : 13 July 2021

Published : 14 July 2021

\section{KEYWORDS:}

Student Perception, Teacher Creativity, Learning Outcomes

\begin{abstract}
Many educational institutions still do not pay attention to the development of learning media, the impact of learning is not effective. This condition certainly demands the creativity of teachers for the development of learning media. This study aims to determine the correlation of students' perceptions of the creativity of PAI teachers with student learning outcomes in PAI lessons. The method used is quantitative, using a descriptive approach and correlational design. The population of this study amounted to 242 students in class VIII. The results of this study can be stated that (1) Students' perceptions of the creativity of PAI teachers vary widely, meaning that there are students who say that the majority of students think that PAI teachers are creative, this is indicated by the number of student participants getting a score of $75.02(42.30 \%)$ in moderate level. (2) Based on the data of PAI learning outcomes, students vary widely, but most students have high learning outcomes with an average of 77.13. The correlation between students' perceptions of PAI teacher creativity and student learning outcomes is 0.502, which means that students' perceptions of PAI teacher creativity and student learning outcomes have a significant relationship.
\end{abstract}

\section{RIWAYAT ARTIKEL}

Diterima : 28 Mei 2021

Direvisi : 12 Juli 2021

Disetujui : 13 Juli 2021

Diterbitkan : 14 Juli 2021

\section{KATA KUNCI:}

Persepsi Siswa, Kreativitas Guru, Hasil belajar

\begin{abstract}
ABSTRAK
Lembaga pendidikan masih banyak tidak memperhatikan pegembangan media pembelajaran, dampaknya pembelajaran tidak efektif. Kondisi ini tentu menuntut kreativitas guru untuk pengembangan media pembelajaran. Penelitian ini bertujuan untuk mengetahui korelasi persepsi siswa tentang kreativitas guru PAI dengan hasil belajar siswa dalam pelajaran PAI. Meode yang digunakan kuantitatif, dengan menggunakan pendekatan deskriptif dan rancangan korelasional. Populasi penelitian ini berjumlah 242 siswa pada kelas VIII. Hasil penelitian ini dapat dikemukakan bahwa (1) Persepsi siswa tentang kreativitas guru PAI sangat bervariasi, artinya ada siswa mengatakan bahwa mayoritas siswa berpendapat guru PAI kreatif, hal ini ditunjukan dengan banyaknya peserta siswa memperoleh nilai $\geq 75,02$ (42,30\%) pada taraf sedang.(2)Berdasarkan data hasil belajar PAI siswa sangat bervariasi, namun kebanyakan siswa hasil belajarnya tinggi dengan rata-rata 77,13. Korelasi persepsi siswa tentang kreativitas guru PAI dengan hasil belajar siswa diperoleh besarnya 0,502 yang berarti persepsi siswa tentang kreativitas guru PAI dengan hasil belajar siswa terdapat hubungan yang signifikan.
\end{abstract}




\section{Fitrah: Journal of Islamic Education}

PENDAHULUAN

Pendidikan merupakan sesuatu yang sangat penting dalam menambah wawasan dan pengetahuan bagi setiap manusia, sehingga dalam islam perintah untuk menuntut ilmu itu menjadi kewajiban bagi setiap individu. Oleh karena itu, dalam menunjang dan meningkatkan pengetahuan terkait agama Islam, maka setiap sekolah memiliki mata pembelajaran agamanya, seperti pendidikan agama Islam. (R. R. Lubis et al., 2020).

Pendidikan Agama Islam adalah salah satu pendidikan dasar yang harus diterima peserta didik dan guru mempunyai tanggung jawab serta peranan penting dalam mengajar, membina dan mendidik siswa agar mampu memahami dan mengamalkan ajaran agama dengan baik dan benar. Guru Agama Islam juga berperan membina aktif seluruh kemampuan dan sikap yang baik dari peserta didik sesuai dengan ajaran Islam. Namun Keberhasilan seorang guru dalam mengajar ditentukan oleh beberapa faktor, baik faktor internal maupun eksternal. Faktor internal terdiri atas motivasi, kepercayaan diri, dan kreativitas guru itu sendiri. Sedangkan faktor eksternal lebih ditekankan pada sarana serta iklim sekolah yang bersangkutan. Setiap kemajuan yang diraih manusia selalu melibatkan kreativitas. (Elismarwati, 2020). Ketika manusia mendambakan produktivitas, efektivitas, efisiensi dan bahkan kebahagiaan yang lebih baik dan lebih tinggi dari apa yang sebelumnya di capai, maka kreativitas dijadikan dasar untuk menggapainya. (Kenedi, 2017). Kreativitas adalah kemampuannya untuk dapat membuat kombinasi baru dari hal-hal yang ada, sehingga proses pembelajaran berjalan dengan lancar, aktif dan siswa dapat megikuti pelajaran dengan baik. Oleh karena itu, seorang guru dalam proses belajar mengajar harus menggunakan variasi metode dalam mengajar, memilih metode yang tepat untuk setiap bahan pelajaran agar peserta didik tidak mudah bosan. (Syaikhudin, 2013). Guru harus terampil dalam mengolah cara pembelajaran, cara membaca kurikulum, cara membuat, memilih dan menggunakan media pembelajaran, dan cara evaluasi baik dengan tes maupun melalui observasi. (Fahmi \& Bitasari, 2021). Evaluasi berfungsi untuk mengukur keberhasilan pencapaian tujuan dan sebagai feed back bagi seorang guru. Guru yang baik dapat mengaktifkan murid dalam hal hasil belajarnya. (Iriani, 2019). Menurut Sardiman menyatakan, bahwa hasil belajar adalah adanya perubahan tingkah laku dalam dirinya. Perubahan tingkah laku tersebut menyangkut baik perubahan yang bersifat pengetahuan (kognitif), keterampilan (psikomotor) maupun yang menyangkut nilai dan sikap (afektif). (Herawati et al., 2019). Oleh karena itu, apabila peserta didik mempelajari pengetahuan tentang konsep, maka 
perubahan perilaku yang diperoleh adalah tidak hanya berupa penguasaan konsep tetapi juga keterampilan dan sikap. Selain itu, Presepsi peserta didik terhadap guru PAI juga memiliki hubungan yang kuat dalam hasil belajar mereka. Persepsi pada hakikatnya adalah proses kognitif yang dialami oleh setiap individu dalam memahami informasi yang datang dari lingkungan melalui inderanya. (Hariyanti, 2013). Dalam buku psikologi perkembangan yang ditulis oleh Desmita, Chaplin mengartikan persepsi sebagai proses mengetahui objek dan kejadian objek dengan bantuan indera. Menurut Atkinson, persepsi adalah proses dimana kita mengorganisasi dan menafsirkan pola stimulus dalam lingkungan. (Triyuni, 2018).

Berdasarkan hasil observasi awal penulis di SMP Negeri 12 x 11 Enam Lingkung. Bahwa masalah yang banyak didapati pada proses pembelajatan siswa pada mata Pembelajaran Pendidikan Agama Islam, diantaranya kurang efektifnya siswa dalam mengikuti pembelajaran, sehingga materi yang diajarkan kepada mereka kurang dipahami. Hal lain, guru yang mengajar Pendidikan Agama Islam belum menggunakan media pembelajaran yang menarik, seperti video, gambar dan lain sebagainya, sehingga ruang kelas dalam proses pembelajaran kurang konduksif dan efesien dalam menarik kefokusan siswanya terhadap pembelajaran yang sedang berlangsung. (Zabidi, 2020).

Pada penulisan artikel ini, penulis menjelaskan beberapa peneliti yang relevan dengan penelitian ini dalam meningkatkan keaktifan siswa dalam proses pembelajaran dan terkhususnya menggunakan media pembelajaran, di antaranya: Pertama, penelitian tentang layanan informasi dengan menggunakan Media Powerpoint dalam meningkatkan aktifitas siswa pada layanan bmbingan dan konseling, hasilnya penggunaan media tersebut lebih diminati dan menambah kefokusan siswa dalam pembelajaran. (Wardiah, 2018). Kedua, kemampuan guru dalam pembuatan media pembelajaran dengan menggunakan video berbasis aplikasi Ms Powerpoint. Hasilnya penelitian menunjukkan bahwa guru yang mampu untuk menggunakan media Powerpoint lebih efektif dalam mencapai tujuan pembelajaran di bandingkan dengan guru yang tidak mampu menggunakannya. (Movitaria, 2021). Ketiga, penelitian tentan multimedia pembelajaran interaktif dalam pembelajaran di era pandemi Covid-19, dimana hasil penelitian menunjukkan bahwa era pandemi Covid-19 sangat membutuhkan media pembelajaran interaktif sebagai pendukung pembelajaran tatap muka. (Manurung, 2021). Keempat, penelitian tentang pemanfaatan media pembelajaran untuk peningkatan kualitas belajar siswa. Hasil penelitian menunjukkan bahwa hasil 
belajar berbanding lurus dengan kualitas pemanfaatan media pembelajaran yang digunaka guru. (M. Lubis et al., 2020). Kelima, transformasi media pembelajaran pada masa pandemi Covid-19. Hasil penelitian menunjukkan bahwa terjadi perubahan yang signifikan pada pemilihan dan rancangan media pembelajaran di masa pandemi Covid-19.(Atsani, 2020).

Dari kelima penelitian tersebut dapat disimpulkan, bahwa kreatifitas seorang guru dalam menyampaikan materi pembelajaran merupakan suatu hal yang sangat mendukung dan menunjang keberhasilan siswa dalam memahami materi yang diajarkan dan salah satu bentuk media yang digunakan yaitu berbasis teknologi. Namun beberapa penelitian tersebut terdapat sisi kosong yang belum terjamah untuk dibahas yakni persepsi siswa tentang kreativitas guru dalam merancang media pembelajaran dan hubungannya dengan hasil belajar. Terkadang kesalahan persepsi siswa memandang media pembelajaran yang dirancang guru menurunkan motivasi dan minat mereka untuk mengikuti pembelajaran, sehingga akhirnya mempengaruhi pencapaian hasil belajar siswa tersebut.

Penelitian ini menjadi sangat urgen, sebab dapat memberikan kontribusi bagi para guru khususnya dalam merancang media pembelajaran, dan memberikan pemahaman kepada siswa terhadap media pembelajaran yang telah dirangcang, sehingga timbul persepsi yang baik, yang akhirnya bermuara pada hasil belajar yang baik pula. Selain itu penelitian ini juga berkontribusi untuk pengelola lembaga pendidikan, dalam hal ini kepala sekolah. Untuk lebih mendorong dan mendukung guru dalam hal pembuatan media pembelajaran.

\section{KAJIAN TEORI}

Secara etimologi, persepsi berasal dari kata "perception" yang berarti pengalaman, pengamatan, rangsangan, dan penginderaan. (Aziz, 2019). Sedangkan menurut etimologi, persepsi merupakan pengalaman tentang objek, peristiwa, atau hubungan yang diperoleh dengan menyimpulkan informasi dan menafsirkan pesan. (Muzlifatin, 2012).

$$
\text { Sedangkan Kreativitas sering }
$$
diartikan sebagai kemampuan untuk mewujudkan sesuatu yang baru. Ia merupakan potensi yang dianugerahkan Allah hanya kepada manusia, bukan kepada malaikat ataupun makhuk lainnya. Oleh sebab itu, keberadaan, fungsi, dan hasil serta kualitas kreativitas itu boleh dijadikan salah satu ciri pembeda antara manusia dengan makhuk lainnya. Kreatifitas juga diartikan sebagai kemampuan untuk mencipta/daya cipta. (Hidayah, 2019).

Bagi seorang guru pendidikan agama Islam sangat dibutuhkan kreativitas, guna 
menemukan cara-cara baru, terutama di dalam menanamkan nilai-nilai ajaran agama pada peserta didik dan kemampuan untuk menemukan cara-cara baru bagi pemecahan problem-problem yang berkaitan dengan pembelajaran. (Syamsurizal et al., 2021). Keduanya kreativitas guru dan hasil belajar siswa tentu menjadi satu hal yang memiliki hubungan, namun seberapa besar hubungan tentu saja membutuhkan penelitan khusus. Namun bisa saja tidak memiliki hubungan disebabkan persepsi yang berbeda tentang fungsi dari kreativitas tersebut. Maka ketiganya seyogianya berjalan beriringan, antara persepsi siswa tentang kreativitas, dan hubungannya dengan hasil belajar siswa. (Fadilah \& Darodjat, 2021).

Untuk lebih jelasnya tentang hubungan antara persepsi tentang kreativitas guru dalam media pembelajaran dengan hasil belajar siswa, dapat dilihat pada skema korelasi seperti yang tertera di bawah ini.

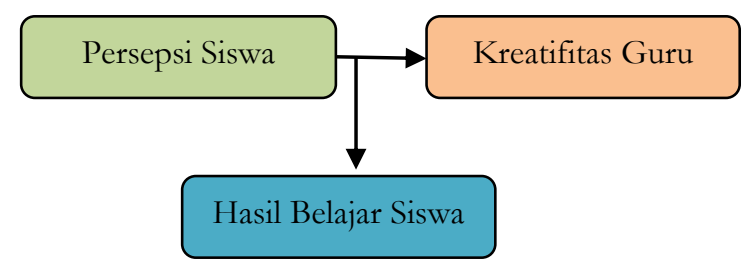

Skema 1: Hubungan Variabel Penelitian

Guru PAI juga harus berpacu dalam proses pembelajaran, dengan memberikan kemudahan belajar bagi seluruh peserta didik, agar dapat mengembangkan potensinya secara optimal. Dalam hal ini, maka seorang guru PAI harus memiliki jiwa yang kreatif, profesional dan menyenangkan, dengan memposisikan dirinya sebagai berikut: (1) Orang tua yang penuh kasih sayang pada peserta didik. (2) teman, tempat mengadu, dan mengutarakanperasaan bagi peserta didik. (3) fasilitator yang selalu siap memberikan kemudahan dan melayani peserta didik sesuai minat, kemampuan, dan bakatnya. (4) memberikan sumbangan pemikiran kepada orang tua untuk dapat mengetahui permasalahan yang dihadapi peserta didik dan memberikan saran pemecahannya. (5) memupuk rasa percaya diri, berani dan brtanggung jawab. (6) Membiasakan peserta didik untuk saling berhubungan dengan orang lain secara wajar. (7) mengembangkan proses sosialisasi yang wajar antar peserta didik, orang lain, dan lingkungannya. (8) mengembangkan kreativitas. (Mufidah, 2013).

\section{METODE PENELITIAN}

Jenis penelitian field research atau penelitian lapangan. penelitian lapangan Dengan menggunakan metode kuantitatif. Penelitian ini bertujuan untuk menunjukkan hubungan antara variabel, menguji teori dan mencari generalisasi yang mempunyai nilai prediksi.

Dalam penelitian ini salah satu yang berhubungan dengan hasil belajar adalah persepsi peserta didik tentang kreativitas guru PAI. Dalam penelitian ini persepsi peserta didik tentang kreativitas guru PAI menjadi variabel bebas atau independent dan hasil belajar peserta didik menjadi variabel 
terikat atau dependent. Hubungan antar variabel berikut digambarkan pada skema pola hubungan sebagai berikut:

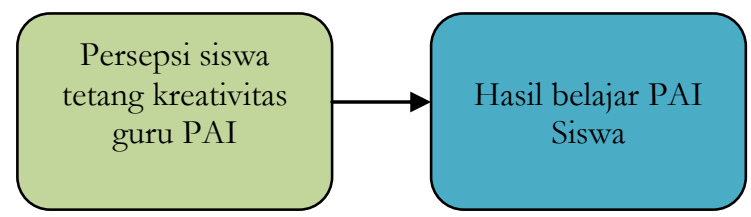

Skema 2: Pola Hubungan Variabel

Teknik pengumpulan data yang digunakan pada penelitian ini, yaitu melalui penyebaran angket (kusioner). Sedangkan untuk teknik analisis data dalam penelitian ini adalah teknik pengolahan data statistik dengan menggunakan analisis korelasional.

Untuk mengetahui hubungan antara persepsi peserta didik tentang kreativitas guru PAI dengan hasil belajar PAI peserta didik pada proses pembelajaran penulis menggunakan teknik analisa korelasional dengan rumus Product Moment Rumus tersebut sebagai berikut:

$$
r_{x y}=\frac{n \sum X Y-\left(\sum X\right)\left(\sum Y\right)}{\sqrt{\left\{n \sum X^{2}-\left(\sum X\right)^{2}\right\}\left\{n \sum Y^{2}-\left(\sum Y\right)^{2}\right\}}}
$$

Keterangan:

$r_{x y}:$ Koefisien korelasi Pearson antara item instrumen yang akan digunakan dengan variabel yang bersangkutan

$\mathrm{X}$ : Skor item instrumen yang akan digunakan

Y : Skor semua item instrumen dalam variabel tersebut

n : Jumlah responden

\section{HASIL DAN PEMBAHASAN PENELITIAN}

Hasil penelitian ini akan membahas terkait dengan korelasi presepsi siswa tentang kreativitas guru dengan hasil belajar pendidikan agama Islam di SMP Negeri 1 2x11 Enam Lingkung.

\section{Persepsi Siswa tentang Kreativitas Guru Pendidikan Agama Islam}

Kreativitas guru meliputi beberapa indikator diantaranya yaitu keterampilan mengajar, motivasi tinggi, demokratis, percaya diri, berpikir divergen. Untuk mengetahui persepsi peserta didik tentang kreativitas guru PAI di SMP Negeri 12 x 11 Enam Lingkung penulis akan menjelaskan berdasarkan indikator-indikator tersebut.

Untuk mengetahui persepsi peserta didik tentang kreativitas guru PAI di SMP Negeri 12 x 11 Enam Lingkung mengenai kreatifitas mengajar penulis jelaskan melalui penyebaran angket kepada 52 peserta didik (responden) yang di jadikan sampel penelitian. Untuk lebih jelasnya hasil nilai angket yang disebarkan sebagai berikut:

Tabel 1. Sebaran Skor angket Presepsi Siswa

\begin{tabular}{|c|c|c|c|c|c|}
\hline $\mathrm{n}$ & Skor & $\mathrm{n}$ & Skor & $\mathrm{n}$ & Skor \\
\hline 1 & 81 & 19 & 75 & 37 & 75 \\
\hline 2 & 81 & 20 & 75 & 38 & 74 \\
\hline 3 & 78 & 21 & 81 & 39 & 81 \\
\hline 4 & 80 & 22 & 85 & 40 & 78 \\
\hline 5 & 82 & 23 & 72 & 41 & 80 \\
\hline 6 & 74 & 24 & 65 & 42 & 70 \\
\hline 7 & 81 & 25 & 71 & 43 & 65 \\
\hline 8 & 76 & 26 & 67 & 44 & 87 \\
\hline 9 & 87 & 27 & 83 & 45 & 86 \\
\hline 10 & 70 & 28 & 82 & 46 & 81 \\
\hline 11 & 78 & 29 & 86 & 47 & 83 \\
\hline 12 & 86 & 30 & 67 & 48 & 86 \\
\hline 13 & 84 & 31 & 80 & 49 & 81 \\
\hline 14 & 80 & 32 & 79 & 50 & 70 \\
\hline 15 & 70 & 33 & 70 & 51 & 80 \\
\hline 16 & 70 & 34 & 85 & 52 & 75 \\
\hline 17 & 87 & 35 & 84 & & \\
\hline 18 & 79 & 36 & 84 & & \\
\hline
\end{tabular}


Berdasarkan hasil angket mengenai persepsi peserta didik tentang kreativitas guru PAI di atas maka dilakukan perhitungan, dan hasilnya menunjukkan bahwa skor tertinggi adalah 87 dan skor angket terendah adalah 65 . Total range dari sebaran data tersebut adalah 22. Hal itu diketahui dari pegurangan skor tertinggi terhadap skor terendah. Besar dan luasnya pengelompokkan data diketahui 2,2 dan dibulatkan menjadi 3.

Perhitungan selanjutnya dengan membuat tabel distribusi frekuensi untuk menghitung mean dan standar deviasi, adapun hasilnya sebagai berikut:

Tabel 2. Mean dan Standar Deviasi Presepsi siswa

\begin{tabular}{|c|c|c|c|c|c|}
\hline Interval & $\mathbf{F}$ & $\mathbf{X}$ & $\mathbf{x}^{\mathbf{2}}$ & $\mathbf{F x}$ & $\mathbf{f x}^{\mathbf{2}}$ \\
\hline $85-87$ & 9 & 86 & 7396 & 774 & 66564 \\
\hline $82-84$ & 7 & 83 & 6889 & 581 & 48223 \\
\hline $79-81$ & 14 & 80 & 6400 & 1120 & 89600 \\
\hline $76-78$ & 4 & 77 & 5929 & 308 & 23716 \\
\hline $73-75$ & 6 & 74 & 5476 & 444 & 32856 \\
\hline $70-72$ & 8 & 71 & 5041 & 568 & 40328 \\
\hline $67-69$ & 2 & 68 & 4624 & 136 & 9248 \\
\hline $64-66$ & 2 & 65 & 4225 & 130 & 8450 \\
\hline & 52 & 604 & 45980 & 4066 & 318985 \\
\hline
\end{tabular}

Langkah selanjutnya adalah mencari Mean dan Standar Deviasi

a) Mean $=\bar{X}=\frac{\sum X}{N}=\frac{4066}{52}=78,2$

b) $\mathrm{SD}=S D=\sqrt{\frac{N X \sum X^{2}-\left(\sum X\right)^{2}}{N(N-1)}}$

$$
\begin{aligned}
& =\sqrt{6134,33-6099,61} \\
& =\sqrt{34,72} \\
& =6,25
\end{aligned}
$$

c. Pengklasifikasian data tentang persepsi peserta didik tentang kretaivitas guru PAI dengan mengemukakan skala 5 sebagai berikut:

$$
\begin{aligned}
& \geq \mathrm{M}+1,5 \mathrm{SD}=78,2+1,5(6,25)=\geq 86,85 \\
& \geq \mathrm{M}+0,5 \mathrm{SD}=78,2+0,5(6,25)=\geq 81,00 \\
& \geq \mathrm{M}-0,5 \mathrm{SD}=78,2-0,5(6,25)=\geq 75,02 \\
& \geq \mathrm{M}-1,5 \mathrm{SD}=78,2-1,5(6,25)=\geq 69,04 \\
& <\mathrm{M}-1,5 \mathrm{SD}=78,2-1,5(6,25)=<69,04
\end{aligned}
$$

Untuk lebih jelasnya uraian di atas dapat dilihat pada tabel berikut:

Tabel 3. Klasifikasi Data Presepsi siswa

\begin{tabular}{|c|c|c|c|c|}
\hline No & Klasifikasi & $\mathbf{n}$ & $\mathbf{0}$ & Nilai \\
\hline 1 & $\geq 86,85$ & 7 & 13,46 & Baik Sekali \\
2 & $\geq 81,00$ & 9 & 17,31 & Baik \\
3 & $\geq 75,02$ & 22 & 42,30 & Sedang \\
4 & $\geq 69,04$ & 10 & 19,24 & Kurang \\
5 & $<69,04$ & 4 & 7,69 & Kurang Sekali \\
\hline & Jumlah & 52 & 100 & \\
\hline
\end{tabular}

Hasil perhitungan juga gambarkan dalam bentuk grafik sebagai berikut:

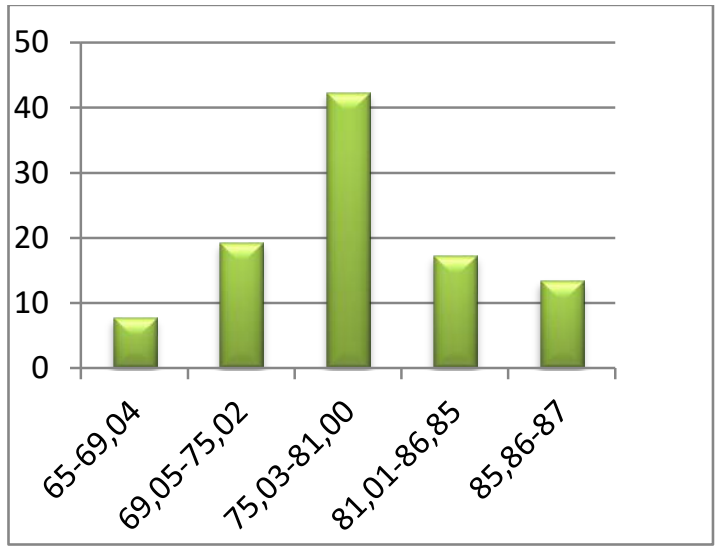

Grafik 1. Klasifikasi Data Presepsi Siswa

Dari grafik diatas terhadap persepsi peserta didik tentang kreativitas guru PAI dalam pembelajaran pendidikan agama Islam bahwa nilai persepsi persepsi siswa tentang kreativitas guru dengan melihat nilai rata- 
rata dan standar deviasi serta dengan menggunakan skala lima yaitu 75,02 $(42,30 \%)$, maka penulis menyimpulkan bahwa persepsi peserta didik tentang kreativitas guru PAI dalam pembelajaran pendidikan agama Islam adalah sedang (biasa-biasa saja) dengan artian tidak terlalu positif dan tidak terlalu negatif.

\section{Hasil Belajar Pendidikan Agama Islam} Siswa

Hasil belajar dapat diartikan sebagai suatu kemampuan internal yang meliputi pengetahuan, keterampilan dan sikap yang ada dalam pribadi seseorang dan memungkinkan seseorang untuk melakukan sesuatu. Menurut Blomm hasil belajar adalah sebagai perubahan tingkah laku yang meliputi tiga ranah yaitu kognif, afektif dan psikomotorik. Nilai Kriteria Ketuntasan Minimal (KKM) yang ditetapkan dalam pembelajaran bidang studi pendidikan agama islam di SMPN 1 2x 11 Enam Lingkung adalah 72 .

Berdasarkan data yang diperoleh tentang hasil belajar PAI siswa maka dilakukan perhitungan, dan hasilnya menunjukkan bahwa skor tertinggi adalah 90 dan skor angket terendah adalah 65 . Total range dari sebaran data tersebut adalah 26. Hal itu diketahui dari pegurangan skor tertinggi terhadap skor terendah. Besar dan luasnya pengelompokkan data diketahui 3 . Selanjutnya akan dipaparkan sebaran data sebagai berikut:
Membuat tabel distribusi frekuensi untuk menghitung Mean dan Standar Deviasi:

Tabel 4. Mean dan Standar Deviasi Hasil Belajar Siswa

\begin{tabular}{|c|c|c|c|c|c|}
\hline Interval & $\mathbf{F}$ & $\mathbf{X}$ & $\mathbf{x}^{\mathbf{2}}$ & $\mathbf{F x}$ & $\mathbf{f x}^{\mathbf{2}}$ \\
\hline $88-90$ & 2 & 89 & 7921 & 178 & 15842 \\
\hline $85-87$ & 6 & 86 & 7396 & 516 & 44376 \\
\hline $82-84$ & 6 & 83 & 6889 & 498 & 41334 \\
\hline $79-81$ & 7 & 80 & 6400 & 560 & 44800 \\
\hline $76-78$ & 9 & 77 & 5929 & 693 & 53361 \\
\hline $73-75$ & 6 & 74 & 5476 & 444 & 32856 \\
\hline $70-72$ & 11 & 71 & 5041 & 781 & 55451 \\
\hline $67-69$ & 4 & 68 & 4624 & 272 & 18496 \\
\hline $64-66$ & 1 & 65 & 4225 & 65 & 4225 \\
\hline Jumlah & 52 & 693 & 53901 & 4007 & 310741 \\
\hline
\end{tabular}

Berikutnya mencari Mean dan Standar Deviasi

a. Mean $=\bar{X}=\frac{\sum X}{N}=\frac{4007}{52}=77,1$

b. $\mathrm{SD}=\sqrt{\frac{\sum f x}{N}}-\left(\frac{\sum f x}{N}\right)^{2}$

$=\sqrt{\frac{310741}{52}}-(77,1)^{2}$

$=\sqrt{5975,79-5944,41}$

$=\sqrt{31,38}$

$=6,1$

c. Pengklasifikasian data tentang persepsi peserta didik tentang kretaivitas guru PAI dengan mengemukakan skala 5 sebagai berikut:

$$
\begin{aligned}
& \geq \mathrm{M}+1,5 \mathrm{SD}=77,1+1,5(6,1)=\geq 88,5 \\
& \geq \mathrm{M}+0,5 \mathrm{SD}=77,1+0,5(6,1)=\geq 79.9 \\
& \geq \mathrm{M}-0,5 \mathrm{SD}=77,1-0,5(6,1)=\geq 74,3 \\
& \geq \mathrm{M}-1,5 \mathrm{SD}=77,1-1,5(6,1)=\geq 68,7 \\
& <\mathrm{M}-1,5 \mathrm{SD}=77,1-1,5(6,1)=<68,7
\end{aligned}
$$


Untuk lebih jelasnya uraian di atas dapat dilihat pada tabel berikut:

Tabel 5. Klasifikasi Data Hasil Belajar Siswa

\begin{tabular}{|c|c|c|c|c|}
\hline No & Klasifikasi & $\mathbf{n}$ & $\mathbf{0}$ & Nilai \\
\hline 1 & $\geq 88,5$ & 2 & 03,84 & Baik Sekali \\
2 & $\geq 79.9$ & 16 & 30,77 & Baik \\
3 & $\geq 74,3$ & 16 & 30,77 & Sedang \\
4 & $\geq 68,7$ & 14 & 26,92 & Kurang \\
5 & $<68,7$ & 4 & 07,70 & Kurang Sekali \\
\hline & Jumlah & 52 & 100 & \\
\hline
\end{tabular}

Hasil perhitungan juga gambarkan dalam bentuk grafik sebagai berikut:

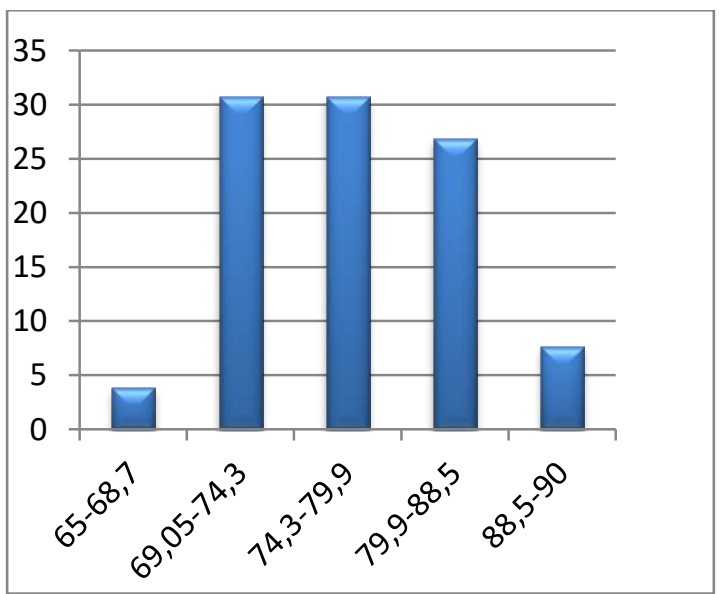

Grafik 2. Hasil Belajar PAI Siswa

Berdasarkan grafik hasil belajar siswa terlihat bahwa rata-rata hasil belajar siwa adalah 74,3 (30,77\%), maka disimpulkan bahwa hasil belajar PAI siswa berada dalam katergori sedang (biasa-biasa saja) dengan artian tidak terlalu tinggi dan tidak terlalu rendah.

\section{Korelasi Persepsi Siswa Tentang Kreativitas Guru PAI dengan Hasil Belajar}

Untuk mencari data hubungan antara persepsi peserta didik tentang kreativitas guru PAI dengan hasil belajar bidang studi PAI di SMP Negeri 12 x 11
Enam Lingkung, maka penulis gunakan teknik korelasi, dalam istilah korelasi diberi pengertian sebagai hubungan antara dua variabel atau lebih.

Dalam hal ini korelasi yang digunakan adalah untuk mengetahui sejauh mana pengaruh antara dua variabel $\mathrm{X}$ dan $\mathrm{Y}$. Dalam mencari hubungan antara 2 variabel tersebut, penulis menggunakan teknik korelasi product moment. Teknik korelasi ini dikembangkan oleh Karl Pearson yang disebut dengan teknik korelasi pearson. Namun sebelum melakukan perhitungan akan dipersiapkan sebaran datanya:

Tabel 6. Sebaran data persepi siswa dan hasil belajar siswa

\begin{tabular}{|c|c|c|c|c|c|}
\hline NO & $\mathbf{X}$ & $\mathbf{Y}$ & $\mathbf{X Y}$ & $\mathbf{X}^{2}$ & $\mathbf{Y}^{2}$ \\
\hline 1 & 81 & 81 & 6561 & 6561 & 6561 \\
\hline 2 & 81 & 89 & 7209 & 6561 & 7921 \\
\hline 3 & 78 & 81 & 6318 & 6084 & 6561 \\
\hline 4 & 80 & 85 & 6800 & 6400 & 7225 \\
\hline 5 & 82 & 85 & 6970 & 6724 & 7225 \\
\hline 6 & 74 & 82 & 6068 & 5476 & 6724 \\
\hline 7 & 81 & 86 & 6966 & 6561 & 7396 \\
\hline 8 & 76 & 85 & 6460 & 5776 & 7225 \\
\hline 9 & 87 & 90 & 7830 & 7569 & 8100 \\
\hline 10 & 70 & 76 & 5320 & 4900 & 5776 \\
\hline 11 & 78 & 81 & 6318 & 6084 & 6561 \\
\hline 12 & 86 & 81 & 6966 & 7396 & 6561 \\
\hline 13 & 84 & 82 & 6888 & 7056 & 6724 \\
\hline 14 & 80 & 72 & 5760 & 6400 & 5184 \\
\hline 15 & 70 & 68 & 4760 & 4900 & 4624 \\
\hline 16 & 70 & 65 & 4550 & 4900 & 4225 \\
\hline 17 & 87 & 71 & 6177 & 7569 & 5041 \\
\hline 18 & 79 & 76 & 6004 & 6241 & 5776 \\
\hline 19 & 75 & 70 & 5250 & 5625 & 4900 \\
\hline 20 & 75 & 77 & 5775 & 5625 & 5929 \\
\hline 21 & 81 & 79 & 6399 & 6561 & 6241 \\
\hline 22 & 85 & 75 & 6375 & 7225 & 5625 \\
\hline 23 & 72 & 67 & 4824 & 5184 & 4489 \\
\hline 24 & 65 & 71 & 4615 & 4225 & 5041 \\
\hline 25 & 71 & 71 & 5041 & 5041 & 5041 \\
\hline 26 & 67 & 72 & 4824 & 4489 & 5184 \\
\hline
\end{tabular}


Fitrah: Journal of Islamic Education

\begin{tabular}{|c|c|c|c|c|c|}
\hline 27 & 83 & 80 & 6640 & 6889 & 6400 \\
\hline 28 & 82 & 71 & 5822 & 6724 & 5041 \\
\hline 29 & 86 & 78 & 6708 & 7396 & 6084 \\
\hline 30 & 67 & 72 & 4824 & 4489 & 5184 \\
\hline 31 & 80 & 73 & 5840 & 6400 & 5329 \\
\hline 32 & 79 & 71 & 5609 & 6241 & 5041 \\
\hline 33 & 70 & 78 & 5460 & 4900 & 6084 \\
\hline 34 & 85 & 75 & 6375 & 7225 & 5625 \\
\hline 35 & 84 & 86 & 7224 & 7056 & 7396 \\
\hline 36 & 84 & 77 & 6468 & 7056 & 5929 \\
\hline 37 & 75 & 87 & 6525 & 5625 & 7569 \\
\hline 38 & 74 & 76 & 5624 & 5476 & 5776 \\
\hline 39 & 81 & 83 & 6723 & 6561 & 6889 \\
\hline 40 & 78 & 76 & 5928 & 6084 & 5776 \\
\hline 41 & 80 & 75 & 6000 & 6400 & 5625 \\
\hline 42 & 70 & 72 & 5040 & 4900 & 5184 \\
\hline 43 & 65 & 68 & 4420 & 4225 & 4624 \\
\hline 44 & 87 & 83 & 7221 & 7569 & 6889 \\
\hline 45 & 86 & 84 & 7224 & 7396 & 7056 \\
\hline 46 & 81 & 82 & 6642 & 6561 & 6724 \\
\hline 47 & 83 & 74 & 6142 & 6889 & 5476 \\
\hline 48 & 86 & 75 & 6450 & 7396 & 5625 \\
\hline 49 & 81 & 78 & 6318 & 6561 & 6084 \\
\hline 50 & 70 & 69 & 4830 & 4900 & 4761 \\
\hline 51 & 80 & 71 & 5680 & 6400 & 5041 \\
\hline 52 & 75 & 79 & 5925 & 5625 & 6241 \\
\hline$\sum$ & 4067 & 4011 & 314690 & 320077 & 311313 \\
\hline
\end{tabular}

Langkah selanjutnya adalah memberikan interpretasi $\mathrm{r} x y$. Untuk melakukan interpretasi terhadap angka korelasi yang telah diperoleh ada beberapa cara yang ditempuh:

a. Merumuskan hipotesis

Hipotesis yang dapat dirumuskan dalam penelitian ini adalah hipotesa alternatif (Ha) yaitu terdapatnya korelasi yang signifikan persepsi peserta didik tentang kreativitas guru PAI denganhasil belajar pendidikan agama Islam peserta didik.

Hipotesa nihil (Ho) yaitu tidak terdapat hubungan yang signifikan antara persepsi peserta didik tentang kreatifitas guru PAI dengan hasil belajar Pendidikan Agama Islam peserta didik.

b. Mencari derajat bebasnya

df

$$
\begin{aligned}
& =\mathrm{N}-\mathrm{nr} \\
& =52-2 \\
& =50
\end{aligned}
$$

c. Berkonsultasi pada " $r$ " tabel

Dengan melihat tabel " $\mathrm{r}$ " product moment maka penulis ketahui df sebesar 50 diperoleh " $\mathrm{r}$ " product moment pada taraf signifikan $5 \%=0,273$ dan taraf signifikansi $1 \%=0,354$

d. Membandingkan besarnya rxy dengan "r" tabel

Seperti diketahui $\mathbf{r} x y=0.502$ sedangkan " $r$ " tabel masing-masing oada taraf 5\% adalah 0,273 dan taraf $1 \%$ 0,354, jadi berdasarkan "r" (rxy) adalah lebih besar dari df baik pada pada taraf signifikan 
$5 \%$ maupun pada taraf signifikan $1 \%$ sehingga Ho ditolak, berarti ada korelasi positif dan signifikan antara variabel $\mathrm{X}$ dan variabel $Y$.

Dari data di atas dapat disimpulkan bahwa ada hubungan antara persepsi peserta didik tentang kreativitas guru PAI dengan hasil belajar PAI peserta didik di SMP negeri 12 x 11 Enam Lingkung kabupaten Padang Pariaman.

e. Interpretasi secara kasar atau sederhana Bila dilihat secara kasar $\mathrm{r} x y \quad 0,502$ terletak antara $0.40-0,70$ berarti antara variabel $\mathrm{X}$ dan variabel $\mathrm{Y}$ terdapat korelasi yang sedang atau cukup. Jadi tinggi rendahnya hasil belajar pendidikan agama Islam kuat hubungannya dengan ada tidaknya kreativitas guru PAI dalam proses belajar mengajar.

f. Uji Asumsi

1. Uji Normalitas

Perhitungan uji asumsi normalitas pada penelitian ini menggunakan SPSS 16.0 for windows yang terdapat dalam lampiran III. Uji normalitas ditentukan untuk melihat penyimpangan frekuensi observasi distribusi gejala yang diteliti dari frekuensi teoritisnya. Suatu data dikatakan normal apabila probabilitas kedua variabel besar $0,05 \quad(\rho>0.05)$. Analisis uji normalitas pada penelitian ini menggunakan program SPSS 16.0 for windows yang terdapat pada lampirkan 3. Pada tabel uji normalitas terlihat probabilitas kedua variabel besar dari $0,05 \rho>$ 0.05). Probabilitas persepsi tentang kreativitas guru PAI 0,186 $(\rho>0.05)$ dan probabilitas hasil belajar PAI peserta didik 0,603 $(\rho>0.05)$. Jadi, data persepsi peserta didik tentang kreativitas guru PAI dan hasil belajar PAI peserta didik berdistribusi normal.

2. Uji Linearitas

Perhitungan uji asumsi linearitas pada penelitian ini menggunakan program SPSS 16.0 for windows yang terdapat pada lampiran 3. Diketahui pada tabel uji linearitas bahwa nilai Fbitung sebesar 16,871 dan probabilitas $(\rho)$ sebesar 0,000 . Nilai tabel F (Ftabed) sebesar 2,25 dengan taraf nyata $\alpha=0,05 \quad(5 \%)$. Berdasarkan hasil perhitungan tampak bahwa Fhitung lebih besar dari Ftabel $(16,871>2,25)$ dan $\rho<$ $0,05(0,000<0,05)$.

Berdasarkan uji asumsi linearitas yang dilakukan dapat disimpulkan bahwa dari variabel kreativitas guru PAI dan hasil belajar peserta didik pada penelitian ini dapat ditarik garis lurus yang menunjukan sebuah bilangan linearitas antara variabelvariabel tersebut. 
3. Uji Hipotesis

Hipotesis pada penelitian ini menyatakan terdapat hubungan positif dan cukup signifikan (meyakinkan) antara persepsi peserta didik tentang kreativitas guru PAI dengan hasil belajar PAI peserta didik. Hipotesis diuji dengan menggunakan uji satu arah. Hasil data dianalisis dengan program SPSS dapat menunjukan semua variabel independen yang dimasukan dalam model mempunyai pengaruh secara bersama-sama atau kombinasi terhadap variabel dependen yang terdapat pada lampiran III.

Pada tabel korelasi terdapat koefisien korelasi pearson (r) sebesar 0,502 dan signifikasi sebesar 0,000 $(\rho<0,01)$. Hal ini berarti terdapat hubungan (korelasi) yang cukup positif antara persepsi peserta didik kreativitas guru PAI dengan hasil belajar PAI peserta didik. Artinya semakin kreatif guru PAI dalam proses belajar mengajar semakin meningkat atau tinggi hasil belajar peserta didik. Sebaliknya kalau semakin kurang kreatif guru PAI dalam proses pembelajaran maka semakin menurun atau rendah hasil belajar peserta didik.

Setelah diperoleh adanya hubungan antara dua variabel maka besarnya pengaruh variabel bebas (kreativitas guru PAI) terhadap variabel terikat (hasil belajar) dapat ditentukan dengan melihat nila $R$ Square. Pada penelitian ini diperoleh $R$ Square seperti pada tabel di bawah ini:

Tabel 7. Uji Hipotesis Penelitian

\begin{tabular}{|l|c|c|c|c|}
\hline \multicolumn{1}{|c|}{ Variabel } & $\begin{array}{c}\text { Rata- } \\
\text { rata }\end{array}$ & $\boldsymbol{R}$ & $\begin{array}{c}\boldsymbol{R} \\
\text { Square } \\
\left(\boldsymbol{R}^{2}\right)\end{array}$ \\
\hline $\begin{array}{l}\text { Persepsi siswa } \\
\text { tentang } \\
\text { Kreativitas guru }\end{array}$ & 77,13 & 0,502 & 0,000 & 0,252 \\
\cline { 1 - 4 } $\begin{array}{l}\text { Hasil Belajar } \\
\text { Peserta Didik }\end{array}$ & 78,21 & & & \\
\hline
\end{tabular}

Nilai $R$ Square $\left(\mathrm{R}^{2}\right)$ yang terdapat pada tabel di ata sebesar 0,252. Nilai 0,252 dalam hal ini menunjukkan bahwa hubungan kreativitas guru PAI terhadap hasil belajar dalam pembelajaran pendidikan agama Islam sebesar $25,2 \%$. Sedangkan sisanya sebesar $74,8 \%$ karena faktor lain yang tidak diteliti dalam penelitian ini.

Berdasarkan analisis korelasi dari pendapat para siswa melalui penyebaran angket kepada responden terkait dengan kreatifitas guru serta dampaknya terhadap hasil belajar siswa, maka hipotesisnya dapat diterima dan terdapat korelasi yang signifikan (meyakinkan) antara persepsi peserta didik tentang kreativitas guru PAI dengan hasil belajar pada mata pelajaran Pendidikan Agama Islam siswa. Dengan demikian para guru dapat meningkatkan kreativitasnya untuk meningkatkan hasil belajar siswa. (Priyanto, 2014)

\section{SIMPULAN}

Berdasarkan data yang penulis peroleh dalam penelitian ini dapat disimpulkan, bahwa Persepsi siswa tentang 
kreativitas guru PAI SMPN 12 x 11 Enam

Lingkung dalam pemebelajaran pendidikan agama Islam berdasarkan data 52 siswa, yaitu bervariasi, ada peserta didik mengatakan bahwa guru PAI sangat kreatif dan ada yang mengatakan cukup kreatif dan ada pula yang menyatakan kurang kreatif. Namun mayoritas siswa berpendapat, bahwa guru PAI cukup kreatif hal ini ditunjukan dengan banyaknya siswa memperoleh nilai $\geq 75,02(42,30 \%)$ pada taraf sedang yaitu 22 siswa. Berdasarkan data hasil belajar sesuai dengan sampel penelitian di perolah perhitungan yang bervariasi seperti sangat tinggi, cukup tinggi, sedang dan rendah, namun kebanyakan siswa hasil belajarnya cukup tinggi yaitu dengan rata-rata 77,13 dengan nilai tertinggi 90 dan terendah 65 . Setelah mencari data hubungan (korelasi) persepsi peserta didik tentang kreativitas guru PAI dengan hasil belajar peserta didik diperoleh 0,502 yang berarti persepsi peserta didik tentang kreativitas guru PAI dengan hasil belajar siswa tedapat hubungan yang signifikan. Korelasi ini berada pada tingkat sedang, jadi persepsi siswa tentang kreativitas guru PAI SMPN 12 x 11 Enam Lingkung cukup mempengaruhi hasil belajar siswa. Dimana semakin kreatif guru PAI maka semakin baik nilai hasil belajar peserta didik sebaliknya semakin kurang kreatif guru PAI maka semakin kurang pula nilai hasil belajar siswa.

\section{DAFTAR PUSTAKA}

Atsani, K. H. L. G. M. Z. (2020). Transformasi media pembelajaran pada masa Pandemi Covid-19. Al-Hikmah: Jurnal Studi Islam, 1(1), 82-93. http://ejournal.kopertais4.or.id/sasam bo/index.php/alhikmah/article/view/ 3905

Aziz, H. (2019). Persepsi guru PAI tentang pelaksanaan supervisi oleh kepala sekolah dengan kreativitas guru dalam mengajar (penelitian guru PAI di SMP se-Kecamatan Cileunyi Kabupaten Bandung). AL Murabi, 5(2), 185-196. https://doi.org/10.53627/jam.v5i2.34 87

Elismarwati. (2020). Persepsi Guru Pendidikan Agama Islam terhadap Pembelajaran dan Kebijakan Pendidikan Selama Pandemi Covid-19. Jurnal As-Salam, 4(2), 231-245. https://doi.org/10.37249/assalam.v4i2.187

Fadilah, A. A. A., \& Darodjat, D. (2021). Kreativitas Guru PAI dalam Penggunaan Media Pembelajaran di SMK Negeri 1 Purwokerto. Alhamra: Jurnal Studi Islam, 1(2), 104-108. http://www.jurnalnasional.ump.ac.id/i ndex.php/Alhamra/article/view/1012 7

Fahmi, F., \& Bitasari, W. (2021). Revitalisasi Implementasi Kurikulum Pendidikan. Al-Fikru: Jurnal Ilmiah, 14(2), 81-91. https://doi.org/10.51672/alfikru.v14i2 .30

Hariyanti, M. L. (2013). Pengaruh persepsi siswa tentang keterampilan penggunaan media pembelajaran oleh Guru PAI terhadap motivasi belajar PAI siswa kelas VIII di SMP Hasanuddin 6 Semarang. IAIN Walisongo.

Herawati, R., Mujahidin, E., \& Al Hamat, A. (2019). Hubungan Motivasi dan Kreativitas Guru dalam Mengajar dengan Hasil Belajar Mata Pelajaran PAI Di Madrasah Aliyah Negeri 4 
Bogor. Jurnal Teknologi Pendidikan, 8(2), 235-246.

Hidayah, N. (2019). Pengaruh persepsi siswa tentang kompetensi guru PAI terhadap motivasi belajar siswa pada mata pelajaran PAI di SMA Surya Buana Kota Malang. Universitas Islam Negeri Maulana Malik Ibrahim.

Iriani, F. (2019). Kreativitas Guru Pendidikan Agama Islam dalam Pemanfaatan Media Pembelajaran dan Kemampuan Siswa dalam Memahami Materi PAI di Sekolah Dasar. Dayah: Journal of Islamic Education, 2(2), 168181.

https://core.ac.uk/download/pdf/228 453344.pdf

Kenedi, K. (2017). Pengembangan Kreativitas Siswa dalam Proses Pembelajaran di Kelas II SMP Negeri 3 Rokan IV Koto. Suara Guru, 3(2), 329348. http://dx.doi.org/10.24014/suara guru.v3i2.3610

Lubis, M., Yusri, D., \& Gusman, M. (2020). Pembelajaran Pendidikan Agama Islam Berbasis E-Learning (Studi Inovasi Pendidik MTS. PAI Medan di Tengah Wabah Covid-19). Fitrah: Journal of Islamic Education, 1(1), 1-15. http://jurnal.staisumateramedan.ac.id/index.php/fitrah/article/ view/1

Lubis, R. R., Mahrani, N., \& Nasution, L. M. (2020). Alternatif Strategi Pembelajaran Selama Pandemi Covid19 di Stai Sumatera Medan. Ansiru PAI: Pengembangan Profesi Guru Pendidikan Agama Islam, 4(1), 1-16. https://doi.org/10.30821/ansiru.v4i1. 8065

Manurung, P. (2021). Multimedia Interaktif Sebagai Media Pembelajaran Pada Masa Pandemi Covid 19. Al-Fikru: Jurnal Ilmiah, 14(1), 1-12. https://doi.org/10.51672/alfikru.v14i1 .33
Movitaria, M. A. (2021). Kemampuan Guru dalam Pembuatan Media Pembelajaran dengan Video Berbasis Aplikasi Ms Powerpoint. Ikbtisar: Jurnal Pengetahuan Islam, 1(1), 17-24. http://ojs.iaisumbar.ac.id/index.php/i khtisar/article/view/2

Mufidah, R. (2013). Hubungan Antara Persepsi Siswa tentang Kompetensi Pedagogik Guru PAI dengan Hasil Belajar pada Siswa Kelas VIII di SMP Negeri 3 Boja Tabun Pelajaran 2012/2013. IAIN Walisongo. http://eprints.walisongo.ac.id/758/

Muzlifatin, M. (2012). Studi Korelasi antara Persepsi Siswa Tentang Kreativitas Guru dalam Pembelajaran dengan Prestasi Belajar PAI Siswa Kelas $V$ di SDN Pabeyan Tambakboyo Tuban Tahun Pelajaran 2011/2012. IAIN Walisongo.

Priyanto, A. (2014). pengembangan kreativitas pada anak usia dini melalui Aktivitas bermain. Jurnal Ilmiah Guru Caraka Olah Pikir Edukatif, 2.

Syaikhudin, A. (2013). Pengembangan Kreativitas Guru dalam Proses Pembelajaran. Lisan al-hal: Jurnal Pengembangan Pemikiran Dan Kebudayaan, 7(2), 301-318. https://journal.ibrahimy.ac.id/index.p $\mathrm{hp} /$ lisanalhal/article/view/66

Syamsurizal, S., Rahim, A., Marseli, A., \& Suwarni, D. (2021). Pengaruh Kualitas Pelayanan dan Religiusitas terhadap Masyarakat dalam Bertransaksi dengan Bank Syariah Mandiri Pariaman. Jurnal Ikhtisar, 1(1), 25-38. http://ojs.iaisumbar.ac.id/index.php/i khtisar/article/view/3

Triyuni, R. (2018). Persepsi Guru Pendidikan Agama Islam Terhadap Penilaian Autentik. di SMA Dharmawangsa Medan. Universitas Islam Negeri Sumatea Utara Medan.

Wardiah, W. (2018). Optimalisasi Layanan Bimbingan Kelompok Dan Konseling Individu Dengan Menggunakan Media 
Power Point sebagai Upaya

Peningkatan Kebiasaan Belajar Siswa

Kelas Ix-I di SMP Negeri 1 Mataram.

Ganec Swara, 12(1), 118-127.

https://doi.org/10.35327/gara.v12i1.2

4

Zabidi, A. (2020). Kreativitas Guru dalam Memanfaatkan Teknologi Sebagai Media Pembelajaran PAI di SD sekecamatan Bawen Kabupaten Semarang. Inspirasi: Jurnal Kajian Dan Penelitian Pendidikan Islam, 3(2), 128144.

https://ejournal.undaris.ac.id/index.ph $\mathrm{p} /$ inspirasi/article/view/134 